\title{
Conditioning and aversion to toxic Solanum bonariense ("naranjillo") leaves in calves
}

\author{
Condicionado e aversão a folhas tóxicas de Solanum bonariense ("naranjillo") em bezerros
}

\author{
Paul Ruiz-Santos ${ }^{\mathrm{I}}$ James Alan Pfister ${ }^{\mathrm{II}}$ José Manuel Verdes $^{\mathrm{I}^{*}}$
}

\section{ABSTRACT}

Solanum bonariense is a perennial poisonous shrub that induces cerebellar cortical degeneration when eaten by cattle. The aim of this research was to outline a protocol to induce a conditioned aversion to this plant. During the pre-conditioning period ten calves $(126 \pm 12 \mathrm{~kg} \mathrm{BW})$ were maintained at half of their normal energy intake with lucerne hay and water ad libitum, to stimulate consumption of $\boldsymbol{S}$. bonariense. Every two days they were offered $100 \mathrm{~g}$ of $\boldsymbol{S}$. bonariense leaves for 5 minutes. Calves began eating the target plant on day 10 and consumed all the plant material on day 12. The conditioning period began after each calf consumed the entire amount of $\boldsymbol{S}$. bonariense for three consecutive sessions. Five animals were randomly selected for conditioning, and after ingestion of $\boldsymbol{S}$. bonariense they were dosed by oral gavage with lithium chloride $(\mathrm{LiCl})$ at $200 \mathrm{mg} \mathrm{kg}^{-1} \mathrm{BW}$ (treated group), while the other five received a similar volume of water by oral gavage (control group). After 2 doses of $\mathrm{LiCl}$ the treated group ate no $\boldsymbol{S}$. bonariense while the control group consumed the entire $100 \mathrm{~g}$. We confirmed that $\mathrm{LiCl}$ is a powerful tool to induce conditioned aversions against $\boldsymbol{S}$. bonariense in calves, which persists for at least 3 months.

Key words: Solanum bonariense, poisonous plants, conditioned taste aversion, calves.

\section{RESUMO}

Solanum bonariense é uma planta tóxica, arbustiva e perene que induz a degeneração cortical cerebelar quando ingerida por bovinos. O presente trabalho objetiva criar um protocolo para induzir aversão condicionada para essa planta em bovinos. Durante o período de adaptação às condições

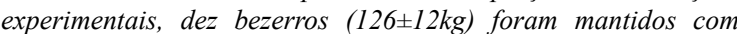
metade de seu fornecimento alimentar energético normal que incluiu feno de alfafa e água ad libitum, para estimular o consumo de $\boldsymbol{S}$. bonariense. A cada dois dias, foram fornecidas oralmente
$100 \mathrm{~g}$ de folhas de $\boldsymbol{S}$. bonariense por cinco minutos. Os bezerros começaram a ingerir a planta no $10^{\circ}$ dia de experimento e consumiram toda a planta no $12^{\circ}$ dia. O periodo condicionado começou após cada bezerro ter consumido a quantidade total de S. bonariense por três sessões consecutivas. Cinco animais foram aleatoriamente selecionados para aversão condicionada e, após ingestão da planta, receberam solução oral de $200 \mathrm{mg} \mathrm{kg}^{-1}$ de peso vivo de cloreto de litio ( $\mathrm{LiCl}$ ) (grupo tratado), enquanto que os outros cinco bovinos receberam dosagem oral com volume similar de solução fisiológica (grupo controle). Após duas doses of $\mathrm{LiCl}$, o grupo tratado não comeu folhas de $\boldsymbol{S}$. bonariense, enquanto que o grupo controle consumiu toda a quantidade fornecida. Os resultados do presente trabalho demonstram que LiCl é uma ferramenta útil para induzir aversão condicionada contra $\boldsymbol{S}$. bonariense em bezerros, que persiste por pelo menos 3 meses.

Palavra-chave: Solanum bonariense, plantas tóxicas, aversão condicionada, bezerros.

\section{INTRODUCTION}

Toxic plants are a serious problem in Uruguay (RIET-CORREA \& MEDEIROS, 2001) and worldwide. In Uruguay, an annual death of 98.000 livestock heads was estimated that is due to toxic plants (RIET-CORREA \& MEDEIROS, 2001). There are at least 31 toxic plant species in Uruguay which belong to 26 genera. Solanum bonariense is a perennial native shrub that is widespread in pastures in Uruguay, Northern Argentina, and Southern Brazil. Although the plant is not highly palatable, it is often consumed by grazing cattle when more desirable forage

\footnotetext{
'Facultad de Veterinaria, Universidad de la República (UDELAR), Av. Alberto Lasplaces, CP 11600, Montevideo, Uruguay. E-mail: jmverdes@fvet.edu.uy. ${ }^{*}$ Corresponding author.

IIUSDA-ARS Poisonous Plant Research Laboratory, Logan, Utah, USA. 
is reduced due to drought or overgrazing (VERDES et al., 2006). When consumed by cattle for extended periods of time, ingestion results in cerebellar cortical degeneration (RIET-CORREA et al., 1983; VERDES et al., 2006). The toxin(s) in the plant is not known, but appears to cause a glycolipid-type storage disease in Purkinje cells (VERDES et al., 2015). This debilitating neurological condition has a low mortality rate but high morbidity in affected animals, as the lesions are permanent (VERDES et al., 2006).

Grazing herbivores normally assess the nutritional value of available pasture and range forages, and generally select a more nutritious diet that is available within a particular environment. Besides selecting nutritious diets, grazing animals generally avoid plants that cause toxicosis or malnutrition (PROVENZA et al., 1992; DUNCAN \& YOUNG, 2002). This selective ability is based on the relationship between the forage flavor (taste and smell) and their post-ingestion nutritional consequences (DUNCAN \& YOUNG, 2002). Animals at times over-ingest toxic plants for reasons that are very complex (PROVENZA et al., 1992). Even so, it is possible to modify herbivore diet selection and improve their diet through the association of a harmful substance with gastric discomfort (PROVENZA, 1996). This process of conditioning as taste aversion can be a useful behavioral tool to train livestock to avoid some toxic plants (RALPHS \& PROVENZA, 1999). Typically aversions are conditioned in livestock using lithium chloride ( $\mathrm{LiCl}$ ) (BURRITT et al., 1990; PROVENZA, 1996; RIET-CORREA \& MEDEIROS, 2001; PFISTER et al., 2002; ALMEIDA et al., 2009). The $\mathrm{LiCl}$ is currently the most widely-used emetic in behavioral studies with animals and in human clinical applications (RALPHS \& PROVENZA, 1999). It causes nausea without dangerous side-effects (PROVENZA et al., 1994; RALPHS \& PROVENZA, 1999). The different methods of administering $\mathrm{LiCl}$ (mixed in food, orally, bolus or subcutaneous or intraperitoneal injections) appear equally effective in creating an aversion (NACHMAN \& ASH, 1973; RALPHS \& PROVENZA, 1999). As a result of its caustic nature the relatively large quantities required to create aversions in livestock (80-200mg/kg BW) must be administered into the rumen either orally in solution or in boluses, allowing dilution in rumen fluid (RALPHS \& PROVENZA, 1999). Li is retained at significant levels in the body for up to $96 \mathrm{~h}$ (RALPHS, 1999). Treated cattle are most severely ill, at second day after dosing, requiring a recovery period of at least 3 d (RALPHS \& PROVENZA, 1999). Aversive conditioning with $\mathrm{LiCl}$ works similarly in goats, horses, sheep and cattle (RALPHS \& OLSEN, 1990; 1992; RALPHS \& CHENEY, 1993; RALPHS et al., 1994; PFISTER \& PRICE, 1996; PFISTER et al., 2002; DUNCAN \& YOUNG, 2002), and has been used to train animals to avoid toxic plants that may vary greatly in palatability (RALPHS et al., 1994; DUMONT \& BOISSY, 1999; MANUELIAN et al., 2010;2014).

The aim of this research was to establish whether $\mathrm{LiCl}$ could be used to induce a conditioned aversion in calves to recently harvested leaves of Solanum bonariense.

\section{MATERIALS AND METHODS}

Location and animals

The experiment was approved by the Facultad de Veterinaria (UdelaR) IACUC, and performed at the Facultad de Veterinaria (UdelaR) Experimental Farm No. 2 (Libertad, San José, Uruguay, $\left.34^{\circ} 40^{\prime} \mathrm{S}, \quad 56^{\circ} 35^{\prime} \mathrm{W}\right)$. Ten crossbred (Holstein x Jersey) males calves $(126 \pm 12 \mathrm{~kg}$ BW) were used; all animals were maintained from birth until their inclusion in the experimental protocol in a $\boldsymbol{S}$. bonariense's free dairy farm, to ensure the same initially naïve condition to the target plant in the group. Five animals were randomly selected to receive the aversion treatment $\left(\mathrm{LiCl}, 200 \mathrm{mg} \mathrm{kg}^{-1}\right.$ orally) while the other five received the same volume of water (control group).

Plant and lithium chloride ( $\mathrm{LiCl})$

Solanum bonariense was collected at the Veterinary School (UdelaR) at Montevideo, Uruguay ( $\left.34^{\circ} 54^{\prime} \mathrm{S}, 56^{\circ} 08^{\prime} \mathrm{W}\right)$, according to VERDES et al. 2006. Recently harvested fresh leaves from several different plants were offered to animals in all the trials. LiCl (Sigma ${ }^{\circledR}$ L4408, St. Louis, USA) was administered in an oral gavage with a final dose of $200 \mathrm{mg} \mathrm{kg}^{-1} \mathrm{BW}$, according to BURRITT et al. (1990). The $\mathrm{LiCl}$ doses at this concentration (BURRITT \& PROVENZA, 1990), and $100 \mathrm{~g}$ of leaves of $\boldsymbol{S}$. bonariense (VERDES et al., 2006) did not adversely affect the health of treated animals.

\section{Experimental Protocol}

Diet to stimulate the consumption of plant (preconditioning): As in other cases of poisonous plants, $\boldsymbol{S}$. bonariense is consumed by cattle mainly during periods of forage scarcity. Since $\boldsymbol{S}$. bonariense 
is naturally unpalatable, we emulated natural forage scarcity by holding animals in a paddock with water and reduced access to hay. Calves were maintained on a diet of lucerne hay, which was equivalent to $50 \%$ of Metabolic Energy (ME) for maintenance requirements for this age and size (Table 1), (ROHWEDER et al., 1978). All animals were observed daily by caretakers, and weighed weekly to avoid significant weight losses which can affect animal welfare.

\section{Conditioning protocol}

To familiarize the animals with the plant, $100 \mathrm{~g}$ of recently harvested leaves were offered individually to each animal every two days at $0800 \mathrm{~h}$ for a $5 \mathrm{~min}$ period after an overnight fast (consumption test). Refusals were weighed. Conditioning began when all calves ate the entire of $100 \mathrm{~g}$ of $\boldsymbol{S}$. bonariense leaves for three consecutive consumption tests. After that conditioning, five calves were randomly chosen and given an oral dose of $\mathrm{LiCl}\left(200 \mathrm{mg} \mathrm{kg}^{-1}\right.$ BW) by gavage immediately after eating the leaves. They were then isolated without food for $30 \mathrm{~min}$, and later returned to the group with access to food; this procedure was repeated twice (i.e., maximum of 2 doses of $\mathrm{LiCl}$ ). The five calves that constituted the control group were dosed with the same volume of water (on a weight basis) simultaneously with the treated group. Three months after the conclusion of the conditioning trials, a final assessment was made to determine if the LiCl-treated calves were still averted. They were again offered $100 \mathrm{~g}$ of recently harvested leaves to each animal for a $5 \mathrm{~min}$ period after an overnight fast. Refusals were weighed.

Statistical analysis

A mixed model repeated measures analysis was done using SAS 9.3 to compare consumption of $\boldsymbol{S}$. bonariense over time after dosing with $\mathrm{LiCl}$.

Table 1 - Chemical analysis of lucerne hay fed to calves to simulate a scarce forage situation and calculated to provide $50 \%$ of their Metabolic Energy (ME) maintenance requirements.

\begin{tabular}{lcl}
\hline COMPONENT & \% fresh basis & \% DM basis \\
\hline Dry matter & 90.27 & --- \\
Ash & 6.28 & 6.96 \\
Neutral detergent fiber & 57.70 & 63.92 \\
Acid detergent fiber & 42.53 & 47.11 \\
Crude Protein & 10.74 & 11.90 \\
\hline
\end{tabular}

$\operatorname{ME}\left(\mathrm{Mcal} \mathrm{kg}^{-1} \mathrm{DM}\right)=1.881($ ROHWEDER et al., 1978).
The model included individual animals nested within treatment, test days, and the day $\mathrm{x}$ treatment interaction. Animals were a random factor in the model, and the covariance structure of the mixed model was selected based on the best fitting model. Means for the test day $\mathrm{x}$ treatment interaction were compared using the Pdiff option in SAS 9.3.

\section{RESULTS}

Plant consumption

Animals were provided with a lucernebased diet (Table 1) equivalent to $50 \%$ of their metabolic energy requirements calculated from NRC (2000) tables. After 10 days, some calves began to consume $\boldsymbol{S}$. bonariense leaves in small amounts, and on day 12, all animals consumed the total amount of offered leaves (Figure 1).

Conditioned taste aversion: There was a day $\mathrm{x}$ treatment interaction $(\mathrm{P}=0.01)$ for consumption of $\boldsymbol{S}$. bonariense leaves (Figure 1). Dosing with $\mathrm{LiCl}$ decreased $(\mathrm{P}=0.004)$ the consumption of $\boldsymbol{S}$. bonariense leaves by about $40 \%$ in the treated calves after one pairing when tested 48 hours later, compared to control animals which ate all of the offered plant material. Treated and control animals differed on all subsequent test days $(\mathrm{P}<0.001)$, as LiCl-treated animals completely refused to eat $\boldsymbol{S}$. bonariense leaves after a second conditioning trial, whereas the control animals ate all of the proffered material (Figure 2). Three months after finishing the trial, the treated animals maintained the aversion and refused to eat $\boldsymbol{S}$. bonariense leaves.

\section{DISCUSSION}

Solanum bonariense is present in pastures, and remains toxic, throughout the year in Uruguay regardless of season (VERDES et al., 2006), thus the plant is a threat to intoxicate cattle whenever conditions favor consumption by livestock. This study

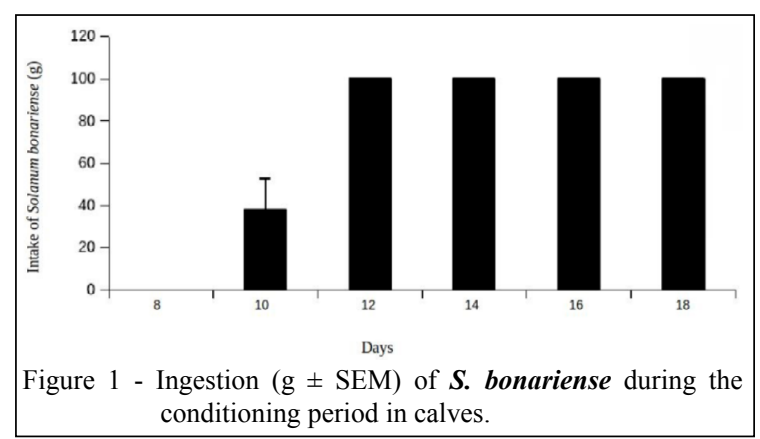

Ciência Rural, v.46, n.4, abr, 2016. 


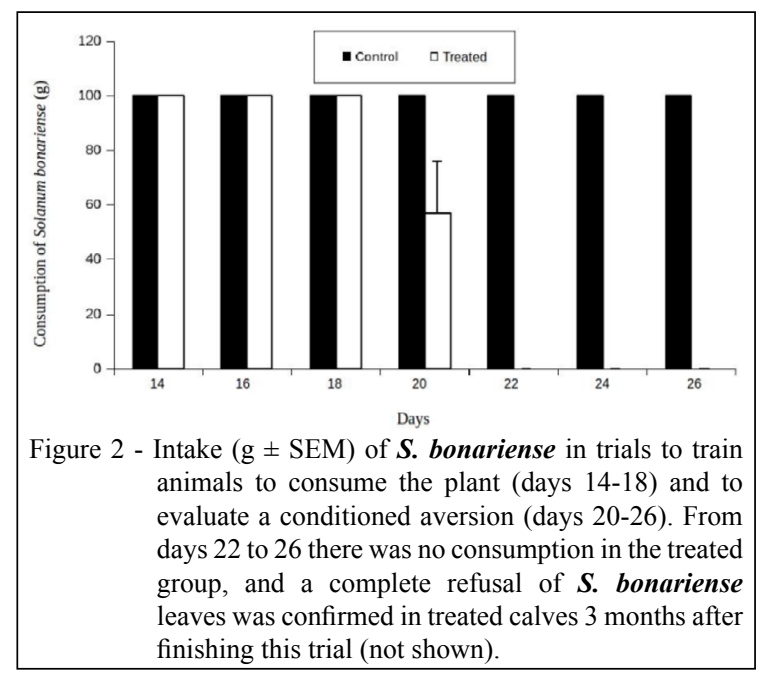

demonstrated that $\mathrm{LiCl}$ at $200 \mathrm{mg} \mathrm{kg}^{-1}$ was an effective and safe tool for inducing a conditioned aversion against $\boldsymbol{S}$. bonariense in calves. Our results confirmed previous reports on the effect of $\mathrm{LiCl}$ as an inducer of aversion to palatable foods in ruminants (BURRITT \& PROVENZA, 1990; RUIZ \& VERDES, 2010). Conditioned aversion has been successfully used to condition cattle (RALPHS \& OLSEN, 1992), sheep (BURRITT \& PROVENZA, 1990), horses (PFISTER et al., 2002), and goats (GORNIAK et al., 2008; OLIVEIRA et al., 2014) to avoid the ingestion of toxic plants. The aversion persisted for at least 3 months in the treated calves, and it is possible that it may have not extinguished for a long period of time. RALPHS reported that cattle averted to toxic but palatable Delphinium species retained the aversion for at least 3 years (RALPHS, 1997).

We also reported that calves eat $\boldsymbol{S}$. bonariense leaves after 10 days when kept under a restrictive diet $(50 \%$ of $\mathrm{ME})$, thus eventually overcoming the neophobia against this shrub, in a similar manner to what likely occurs during spontaneous poisoning during the dry season or during periods of forage shortages due to drought or overgrazing (VERDES et al., 2006). This suggests that on farms where cattle are periodically poisoned with this plant, cattle must have a reduced allotment of desirable forage for about 10 days before they will voluntarily consume $\boldsymbol{S}$. bonariense while grazing. Therefore, cattle producers with this troublesome weed need to define a specific strategy to prevent its consumption by cattle during the dry season when forage is often scarce, and avoid overgrazing during other seasons to prevent potential intoxication. The implementation of a conditioning aversion protocol with $\mathrm{LiCl}$ could be a useful tool to reduce or eliminate
S. bonariense poisoning in this and other regions in South America where the plant causes intoxication.

In our experimental conditions $\mathrm{LiCl}$ produced an aversion to $\boldsymbol{S}$. bonariense in calves. Two doses were sufficient for the calves to associate the adverse effects from $\mathrm{LiCl}$ with this specific poisonous shrub. Other studies suggested that in some cases, it is necessary to repeatedly dose with $\mathrm{LiCl}$ to produce an aversion (BURRITT \& PROVENZA, 1990). In this study, only a second reinforcing dose was needed for calves to develop a strong aversion against $\boldsymbol{S}$. bonariense. Conditioned aversion appears to be a potentially useful tool to reduce or eliminate consumption of $\boldsymbol{S}$. bonariense in calves. It could be a valuable strategy for farms affected by spontaneous intoxication in cattle from $\boldsymbol{S}$. bonariense. Future research is necessary to determine the length of time that calves will maintain the aversion against $\boldsymbol{S}$. bonariense. Further study will also be required to determine if non-naïve cattle that have ingested the plant while grazing, but are not yet intoxicated, can be averted (PFISTER et al., 2007) to S. bonariense. Future aversion studies should include goats and sheep as animal models because they are also intoxicated by this plant (VERDES et al., 2012).

\section{CONCLUSION}

A reduction in the daily energy intake to $50 \%$ of requirements for 10 days induced calves to consume the unpalatable $\boldsymbol{S}$. bonariense. Two doses of $\mathrm{LiCl}$ produced an aversion to $\boldsymbol{S}$. bonariense in calves, which persisted for at least 3 months.

\section{ACKNOWLEDGMENTS}

The authors gratefully acknowledge Elena de Torres (DVM, MSc), Sebastian Brambillasca (DVM, MSc), and Ricardo Pautassi (PhD) for their contributions. This research was supported by "Comisión Sectorial de Investigación Científica de la Universidad de la República" (CSIC, UdelaR), "Comisión de Investigación y Desarrollo Científico" (Facultad de Veterinaria, UdelaR) and "Programa de Desarrollo de las Ciencias Básicas" (PEDECIBA), Uruguay. JMV is a Researcher Career Member of the "Sistema Nacional de Investigadores" (SNI-ANII), Uruguay.

\section{BIOETHICS AND BIOSSECURITY COMMITTE APPROVAL}

The experiment was approved by the Institutional Animal Care and Use Committee of Facultad de Veterinaria (CEUAFVET, UdelaR), No. CEUAFVET-TG 02 - Exp. 111130-000273-14.

\section{REFERENCES}

ALMEIDA, M.B. et al. Conditioned aversion in sheep induced by Baccharis coridifolia. Applied Animal Behaviour Science, v.117, p.197-200, 2009.

Ciência Rural, v.46, n.4, abr, 2016. 
BURRITT, E.A.; PROVENZA, F.D. Food aversion learning in sheep: persistence of conditioned taste aversions to palatable shrubs (Cercocarpus montanus and Amelanchier alnifolia). Journal of Animal Science, v.68, p.1003-1007, 1990.

DUMONT, B.; BOISSY, A. Relations sociales et comportement alimentaire au paturage. INRA Production Animals, v.12, p.3-10, 1999.

DUNCAN, A.J.; YOUNG, S.A. Can goats learn about foods through conditioned food aversions and preferences when multiple food options are simultaneously available?. Journal of Animal Science, v.80, p.2091-2098, 2002.

GORNIAK, S.L. et al. A note on averting goats to a toxic but palatable plant, Leucaena leucocephala. Applied Animal Behaviour Science, v.111, p.396-401, 2008.

MANUELIAN, C.L. et al. Conditioned aversion to olive tree leaves (Olea europaea L.) in goats and sheep. Applied Animal Behaviour Science, v.128, p.45-49, 2010.

MANUELIAN, C.L. et al. Effect of breed and lithium chloride dose on the conditioned aversion to olive tree leaves (Olea europaea L.) of sheep. Applied Animal Behaviour Science, v.155, p.42-48, 2014.

NACHMAN, M.; ASHE, J.H. Learned taste aversions in rats as a function of dosage, concentration, and route of administration of LiCl. Physiology and Behaviour, v.10, p.73-78, 1973.

NRC (NATIONAL RESEARCH COUNCIL). Nutrient requirements of beef cattle. 7.rev. ed. Washington, D.C.: National Academy, 2000. 248 p.

OLIVEIRA JÚNIOR, C.A. et al. Conditioned food aversion to control poisoning by Ipomoea carnea subsp. fistulosa in goats. Ciência Rural, v.44, p.1240-1245, 2014.

PFISTER, J.A.; PRICE, K.W. Lack of maternal influence of lamb consumption of locoweed (Oxytropis sericea). Journal of Animal Science, v.74, p.340-344, 1996.

PFISTER, J.A. et al. Conditioning taste aversions to locoweed (Oxytropis sericea) in horses. Journal of Animal Science, v.80, p.79-83, 2002.

PFISTER, J.A. et al. Effect of previous locoweed (Astragalus and Oxytropis species) intoxication on conditioned taste aversions in horses and sheep. Journal of Animal Science, v.85, p.1836-1841, 2007.

PROVENZA, F.D. Acquired aversions as the basis for varied diets of ruminants foraging on rangelands. Journal of Animal Science, v.74, p.2010-2020, 1996.

PROVENZA, F.D. et al. Antiemetic drugs attenuate food aversions in sheep. Journal of Animal Science, v.72, p.1989-1994, 1994.
PROVENZA, F.D. et al. Mechanisms of learning in diet selection with reference to phytotoxicosis in herbivores. Journal of Range Management, v.45, p.36-45, 1992.

RALPHS, M.H.; OLSEN, J.D. Adverse influence of social facilitation and learning context in training cattle to avoid eating larkspur. Journal of Animal Science, v.68, p.1944-1952, 1990.

RALPHS, M.H.; OLSEN, J.D. Comparison of larkspur alkaloid extract and lithium chloride in maintaining cattle aversion to larkspur in the field. Journal of Animal Science, v.70, p.1116-1120, 1992.

RALPHS, M.H.; CHENEY, C.D. Influence of cattle age, lithium chloride dose level, and food type in the retention of food aversions. Journal of Animal Science, v.71, p.373-379, 1993.

RALPHS, M.H. et al. Social facilitation influences cattle to graze locoweed. Journal of Range Management, v.47, p.123-126, 1994.

RALPHS, M.H. Persistence of aversions to larkspur in naive and native cattle. Journal of Range Management, v.50, p.367-370, 1997.

RALPHS, M.H.; PROVENZA, F. Conditioned food aversions: principles and practices, with especial reference to social facilitation. Proceedings of the Nutrition Society, v.58, p.813-820, 1999.

RIET-CORREA, F. et al. Intoxication by Solanum fastigiatum var. fastigiatum as a cause of cerebellar degeneration in cattle. Cornell Veterinarian, v.73, p.240-256, 1983.

RIET-CORREA, F.; MEDEIROS, R.M.T. Intoxicações por plantas em ruminantes no Brasil e no Uruguai: importância econômica, controle e riscos à saúde pública. Pesquisa Veterinária Brasileira, v.21, p.38-41, 2001.

ROHWEDER, D.A. et al. Proposed hay grading standards based on laboratory analyses for evaluating quality. Journal of Animal Science, v.47, p.747-759, 1978.

RUIZ, P.; VERDES, J.M. Mediación social en el consumo de alimentos en ovinos: condicionamiento jerárquico por edad como herramienta para controlar la dieta en rumiantes no emparentados en pastoreo. Revista Argentina de Ciencias del Comportamiento, v.2, p.14-20, 2010.

VERDES, J.M. et al. Cerebellar degeneration in cattle grazing Solanum bonariense (Naranjillo) in Western Uruguay. Journal of Veterinary Diagnostic Investigation, v.18, p.299-303, 2006.

VERDES, J. M. et al. Cerebellar cortical degeneration in cattle poisoned with Solanum spp. in South America: An epidemiological, clinicopathological, pathological, and toxicological review. International Journal of Poisonous Plant Research, v.2, p.34-44, 2012.

VERDES, J.M. et al. A novel pathogenic mechanism for cerebellar lesions produced by Solanum bonariense in cattle. Journal of Veterinary Diagnostic Investigation, v.27, p.278-286, 2015. 